\title{
Taxonomy of Australian clinical isolates of the genus Photorhabdus and proposal of Photorhabdus asymbiotica subsp. asymbiotica subsp. nov. and $P$. asymbiotica subsp. australis subsp. nov.
}

\author{
R. J. Akhurst, ${ }^{1}$ N. E. Boemare, ${ }^{2}$ P. H. Janssen, ${ }^{3}$ M. M. Peel, ${ }^{3}$ D. A. Alfredson ${ }^{4}$ \\ and C. E. Beard ${ }^{1}$ \\ 'Division of Entomology, Commonwealth Scientific and Industrial Research Organization, \\ Canberra ACT 2601, Australia \\ ${ }^{2}$ Ecologie microbienne des Insectes et Interaction Hôte-pathogène Unité EMIP INRA 1133, \\ Université Montpellier II, 34095 Montpellier CEDEX 5, France \\ ${ }^{3}$ Department of Microbiology and Immunology, University of Melbourne, Vic. 3010, Australia \\ ${ }^{4}$ Gold Coast Hospital, Southport Old 4215, Australia
}

Correspondence

R. J. Akhurst

Ray.Akhurst@csiro.au
The relationship of Photorhabdus isolates that were cultured from human clinical specimens in Australia to Photorhabdus asymbiotica isolates from human clinical specimens in the USA and to species of the genus Photorhabdus that are associated symbiotically with entomopathogenic nematodes was evaluated. A polyphasic approach that involved DNA-DNA hybridization, phylogenetic analyses of $16 \mathrm{~S}$ rRNA and gyrB gene sequences and phenotypic characterization was adopted. These investigations showed that $g y r B$ gene sequence data correlated well with DNA-DNA hybridization and phenotypic data, but that 16S rRNA gene sequence data were not suitable for defining species within the genus Photorhabdus. Australian clinical isolates proved to be related most closely to clinical isolates from the USA, but the two groups were distinct. A novel subspecies, Photorhabdus asymbiotica subsp. australis subsp. nov. (type strain, $9802892^{\top}=\operatorname{CIP} 108025^{\top}=$ ACM $5210^{\top}$ ), is proposed, with the concomitant creation of Photorhabdus asymbiotica subsp. asymbiotica subsp. nov. Analysis of gyrB sequences, coupled with previously published data on DNA-DNA hybridization and PCR-RFLP analysis of the 16S rRNA gene, indicated that there are more than the three subspecies of Photorhabdus luminescens that have been described and confirmed the validity of the previously proposed subdivision of Photorhabdus temperata. Although a non-luminescent, symbiotic isolate clustered consistently with $P$. asymbiotica in gyrB phylogenetic analyses, DNA-DNA hybridization indicated that this isolate does not belong to the species $P$. asymbiotica and that there is a clear distinction between symbiotic and clinical species of Photorhabdus.

\section{INTRODUCTION}

Photorhabdus spp. are generally found in symbiotic association with entomopathogenic nematodes (Heterorhabditis spp.) or in the cadavers of insects infected with these nematodes (Poinar et al., 1980; Boemare et al., 1993). The bacteria are transported into the haemocoel of a host insect within the intestinal tract of infective-stage nematodes,

The GenBank/EMBL/DDBJ accession numbers for the gyrB gene sequences determined in this study are AY278492-AY278517 and AY322432 and those for the 16S rDNA sequences are AY216500, AY217761 and AY280572-AY280574. where they multiply, killing the host and producing conditions that are favourable for the nematodes' maturation and reproduction. Two phases are recognized in Photorhabdus, with phase I being isolated from wild-type Heterorhabditis infective juveniles and phase II appearing in laboratory cultures (Akhurst, 1980; Boemare \& Akhurst, 1988). Photorhabdus-Heterorhabditis associations have become important biopesticides, particularly as the nematodes are mobile and can locate insect pests in cryptic habitats (Bedding \& Miller, 1981).

Farmer et al. (1989) reported the isolation of Photorhabdus from human clinical specimens in the USA. Six isolates were 
recovered from several states over the period 1977-1989. The route of infection could not be ascertained and no further isolations have been reported from the USA. These isolates were very homogeneous and were shown to constitute a fifth DNA hybridization group, distinct from nematode-symbiotic Photorhabdus (Farmer et al., 1989). Fischer-Le Saux et al. (1999) included these isolates in their polyphasic examination of the taxonomy of the genus Photorhabdus and concluded that they constituted a separate species from any of the nematode-symbiotic Photorhabdus spp. They designated the novel species Photorhabdus asymbiotica. No phase I isolates of this species have been reported.

Peel et al. (1999) subsequently reported the isolation of Photorhabdus sp. from four human infections in two Australian states between 1994 and 1998. PCR-RFLP analysis of the 16S rRNA gene showed that these Australian isolates were also highly homogeneous, but distinct from the American isolates. It was not clear from the analysis whether the American isolates were more similar to the Australian isolates or to some symbiotic Photorhabdus isolates (Peel et al., 1999). Two more isolations were performed subsequently (Gerrard et al., 2003).

A polyphasic approach to the taxonomic study of the Australian clinical isolates was conducted, in order to determine their relationship to clinical and symbiotic bacteria of the genus Photorhabdus. The isolates were characterized phenotypically by biochemical and morphological tests. DNA-DNA relatedness was assessed by measurement of reassociation and $\Delta T_{\mathrm{m}}$ of heterologous DNA. In addition to sequencing the 16S rRNA gene for comparison with sequences in various databases, the gyrB gene of the Australian clinical isolates and Photorhabdus isolates that are representative of the taxonomic groups described by Fischer-Le Saux et al. (1999) was sequenced for phylogenetic analysis. The sequence of the gyrB gene has proven to be useful for investigating the intrageneric relationships of disparate groups of bacteria (Venkateswaran et al., 1999; Kasai et al., 2000; Yamamoto et al., 2000). The polyphasic taxonomic study indicated that human clinical isolates of Photorhabdus fall into two distinct subspecies of $P$. asymbiotica.

\section{METHODS}

Bacteria. Clinical isolates (Table 1) were provided by the Microbiological Diagnostic Unit of the University of Melbourne, the Gold Coast Hospital and the Centers for Disease Control and Prevention (USA). Symbiotic isolates were obtained from the CSIRO Entomology collection.

Phenotypic characterization. Phenotypic tests were conducted on isolates MB, 9800946 and $9802892^{\mathrm{T}}$, as well as on isolates 9802336 , 9802397 and 9805888 , which were obtained from the same patient as isolate $9802892^{\mathrm{T}}$. Most phenotypic tests were conducted by following the methods of Fischer-Le Saux et al. (1999). Acid production from and assimilation of carbon sources was tested with API kits (bioMérieux). Luminescence was assessed visually by observation after 10 min dark-adaptation and by analysis of a just visibly turbid aqueous suspension of cells from a $24 \mathrm{~h}$ nutrient broth (Oxoid) culture in a Beckman LS2800 scintillation counter, on the tritium setting. Insect pathogenicity was assessed by the insect pin test of Peel et al. (1999). Maximum temperature for growth was determined in nutrient broth that was inoculated from a $24 \mathrm{~h}$ nutrient broth culture that had been incubated in a water bath with accuracy of $\pm 0 \cdot 2{ }^{\circ} \mathrm{C}$ for $48 \mathrm{~h}$; the five $P$. asymbiotica isolates from the USA (Table 1) were tested simultaneously with the seven Australian clinical isolates.

DNA isolation. DNA was isolated from cells harvested from $24 \mathrm{~h}$ nutrient broth (Oxoid) cultures by using a Qiagen DNeasy kit.

PCR amplification and sequencing of the 16S rRNA gene. The prokaryote-specific primers of Fischer-Le Saux et al. (1999) were used in PCR amplification of the 16S rRNA gene. PCR was performed on $0.3 \mu \mathrm{g}$ target DNA in $100 \mu \mathrm{l}$ Gibco PCR mix that contained $4 \mathrm{mM} \mathrm{MgCl}, 1 \mathrm{mM}$ each dNTP, $25 \mathrm{pM}$ each primer, $100 \mu \mathrm{g}$ cresol red, $13 \%(\mathrm{w} / \mathrm{v})$ sucrose and $2.5 \mathrm{U}$ Taq DNA polymerase (Gibco). Reactions were run on a Corbett FTS 320 thermocycler, with 35 cycles of denaturation at $94^{\circ} \mathrm{C}$ for 1 min, annealing at $55^{\circ} \mathrm{C}$ for $1 \mathrm{~min}$ and extension at $72{ }^{\circ} \mathrm{C}$ for $2.5 \mathrm{~min}$, followed by a final extension at $72^{\circ} \mathrm{C}$ for $3 \mathrm{~min}$ and a renaturation step at $25^{\circ} \mathrm{C}$ for $10 \mathrm{~min}$. The completed reactions were electrophoresed on $1.5 \%$ $(\mathrm{w} / \mathrm{v})$ agarose gel at $5 \mathrm{~V} \mathrm{~cm}^{-1}$. The band was excised and the amplicon was purified with a NucleoTrap Gel Extraction kit (Clontech), cloned into a pGEM-T Easy vector (Promega) and transformed into Escherichia coli strain DH10 $\beta$ by electroporation. In order to identify and eliminate nucleotide changes that were introduced during PCR, four individual clones recovered from each ligation were sequenced with the primer set described by Fischer-Le Saux et al. (1999). Sequencing reactions were performed with an ABI Prism Dye Terminator cycle sequencing ready reaction kit and analysed with an ABI 373A automated sequencer, under the conditions recommended by the manufacturer (Perkin Elmer). The consensus sequence of the four clones was used in subsequent phylogenetic analysis.

PCR amplification and sequencing of the gyrB gene. PCR amplification of $g y r B$ genes was performed with the universal primers of Yamamoto \& Harayama (1995). PCR was carried out on $50 \mathrm{ng}$ target DNA in $20 \mu \mathrm{l}$ Dynazyme buffer that contained $2.5 \mathrm{mM}$ each dNTP, $10 \mu \mathrm{M}$ each primer and $1 \mathrm{U}$ Dynazyme EXT DNA polymerase. Reactions were run on a Corbett FTS 320 thermocycler, with a 2 min denaturation step at $94^{\circ} \mathrm{C}$, followed by 34 cycles of denaturation at $94^{\circ} \mathrm{C}$ for $30 \mathrm{~s}$, annealing at $58^{\circ} \mathrm{C}$ for $30 \mathrm{~s}$ and extension at $72{ }^{\circ} \mathrm{C}$ for $75 \mathrm{~s}$. A final extension was conducted at $72{ }^{\circ} \mathrm{C}$ for $2 \mathrm{~min}$ and was followed by a renaturation step at $25^{\circ} \mathrm{C}$ for $5 \mathrm{~min}$.

gyrB amplicons were sequenced with primers UP-1S and UP-2Sr (Yamamoto \& Harayama, 1995) and UP-3Sr (5'-AGAAGAGAATTTTGGATCAG-3'). Sequencing reactions were performed with an ABI Prism Dye Terminator cycle sequencing ready reaction kit and analysed with an ABI 373A automated sequencer, under the conditions recommended by the manufacturer (Perkin Elmer).

Phylogenetic analyses. 16S rRNA and gyrB gene sequences were aligned against homologous sequences (see Figs 1 and 2) by using the program CLUSTAL X version 1.81 (Thompson et al., 1997). This alignment was then checked manually and corrected, and regions of uncertain alignment were eliminated, with the software SEAL version 1.d1 (A. Rambaut, Department of Zoology, University of Oxford, UK). Further analyses were restricted to the unambiguously aligned regions, totalling 1400 positions of the $16 \mathrm{~S}$ rRNA gene and 1129 positions of gyrB.

Evolutionary analyses were carried out with the PHYLIP package version 3.573c (J. Felsenstein, Department of Genome Sciences, 
Table 1. Photorhabdus isolates used in this study

\begin{tabular}{|c|c|c|c|}
\hline Species/isolate no. & Host & $\begin{array}{c}\text { Geographical } \\
\text { origin }\end{array}$ & Reference \\
\hline \multicolumn{4}{|c|}{ P. luminescens subsp. luminescens: } \\
\hline $\mathrm{Hb}^{\mathrm{T}}$ & Heterorhabditis bacteriophora Brecon* & Australia & Poinar et al. (1977) \\
\hline $\mathrm{Hm}$ & Heterorhabditis sp. $\dagger$ & USA & Bleakley \& Nealson (1988) \\
\hline \multicolumn{4}{|c|}{ P. luminescens subsp. akhurstii: } \\
\hline D1 & Heterorhabditis indica & Australia & Akhurst (1983) \\
\hline Tetuan & Heterorhabditis sp. & Cuba & Akhurst et al. (1996) \\
\hline K81 & Heterorhabditis sp. & Guadeloupe & Akhurst et al. (1996) \\
\hline \multicolumn{4}{|c|}{ P. luminescens subsp. laumondii: } \\
\hline K80 & Heterorhabditis sp. & Argentina & Akhurst et al. (1996) \\
\hline HP88 & Heterorhabditis bacteriophora HP88* & USA & Akhurst et al. (1996) \\
\hline \multicolumn{4}{|l|}{ P. luminescens: } \\
\hline $\mathrm{C} 8404$ & Heterorhabditis sp. (indica?) $\ddagger$ & China & Akhurst (1987) \\
\hline C8406 & Heterorhabditis sp. (bacteriophora?) $\ddagger$ & China & Akhurst (1987) \\
\hline HV16 & Heterorhabditis bacteriophora HV16* & Australia & Akhurst et al. (1996) \\
\hline \multicolumn{4}{|l|}{ P. temperata: } \\
\hline $\mathrm{C} 1$ & Heterorhabditis bacteriophora $\mathrm{NC}^{*}$ & USA & Akhurst (1983) \\
\hline NZH3 & Heterorhabditis zealandica & New Zealand & Akhurst (1987) \\
\hline Meg & Heterorhabditis megidis & USA & Poinar et al. (1987) \\
\hline Habana & Heterorhabditis sp. & Cuba & Akhurst et al. (1996) \\
\hline HF85 & Heterorhabditis megidis & The Netherlands & Smits \& Ehlers (1991) \\
\hline HL81 & Heterorhabditis megidis & The Netherlands & Smits \& Ehlers (1991) \\
\hline HW79 & Heterorhabditis megidis & The Netherlands & Smits \& Ehlers (1991) \\
\hline $\mathrm{XINach}^{\mathrm{T}}$ & Heterorhabditis megidis & Russia & Akhurst (1987) \\
\hline XlLit & Heterorhabditis megidis & Lithuania & Akhurst et al. (1996) \\
\hline Photorhabdus sp. Q614(A) & Heterorhabditis sp. & Australia & Akhurst et al. (1992) \\
\hline \multicolumn{4}{|l|}{ P. asymbiotica: } \\
\hline $1216-79$ & Blood, 73-year-old female & USA & Farmer et al. (1989) \\
\hline $2407-88$ & Abdomen and submandible, 36-year-old female & USA & Farmer et al. (1989) \\
\hline $2617-87$ & Lesion cavity, 45-year-old male & USA & Farmer et al. (1989) \\
\hline $3105-77$ & Blood, 80-year-old female & USA & Farmer et al. (1989) \\
\hline $3265-86^{\mathrm{T}}$ & Pre-tibial wound, 78-year-old male & USA & Farmer et al. (1989) \\
\hline \multicolumn{4}{|l|}{ Photorhabdus sp.: } \\
\hline $\mathrm{MB}$ & Skin biopsy abscess, 55 -year-old male & Australia & Peel et al. (1999) \\
\hline 9800946 & Blood, 90-year-old male & Australia & Peel et al. (1999) \\
\hline $9802336 \$$ & Abscess, 50-year-old male & Australia & Peel et al. (1999) \\
\hline $9802397 \S$ & Abscess, 50-year-old male & Australia & Peel et al. (1999) \\
\hline $9802892^{\mathrm{T}} \S$ & Abscess, 50-year-old male & Australia & Peel et al. (1999) \\
\hline $9805888 \$$ & Abscess (granulomatous tissue), 50-year-old male & Australia & Peel et al. (1999) \\
\hline GCH001 & Pus, 78-year-old male & Australia & Gerrard et al. (2003) \\
\hline
\end{tabular}

${ }^{\star}$ As there is some uncertainty about the homogeneity of the species $H$. bacteriophora, we have adopted the convention of Fischer-Le Saux et al. (1999) and included isolate names to distinguish the different designations.

$\dagger$ The nematode host of isolate $\mathrm{Hm}$ has never been positively identified, though it is often referred to as $H$. bacteriophora.

$¥$ The tentative identifications are based on the isozyme analysis of Akhurst (1987).

§These four isolates were obtained from the same patient, albeit at different times and from different sites (e.g. upper left arm, upper left leg).

University of Washington, Seattle, USA; Felsenstein, 1989). Evolutionary distances between pairs of micro-organisms were determined with the correction of Jukes \& Cantor (1969), implemented in the DNADIST program, and phylograms were derived with the FITCH and NEIGHBOR programs, employing least-squares (Fitch \& Margoliash, 1967) and neighbour-joining (Saitou \& Nei, 1987) algorithms, respectively. Significance of nodes was tested by bootstrap analysis that generated evolutionary distances and used neighbour-joining to produce 1000 trees, and then by compiling a consensus tree, using the programs SEQBOOT, DNADIST, NEIGHBOR or FITCH and CONSENSE. Maximum-likelihood and maximum-parsimony analyses of the sequence data employed the programs DNAML and DNAPARS, respectively. Sequences used as outgroups were the 16S rRNA gene sequences of E. coli (GenBank accession no. J01695) and Proteus vulgaris (X07652) 


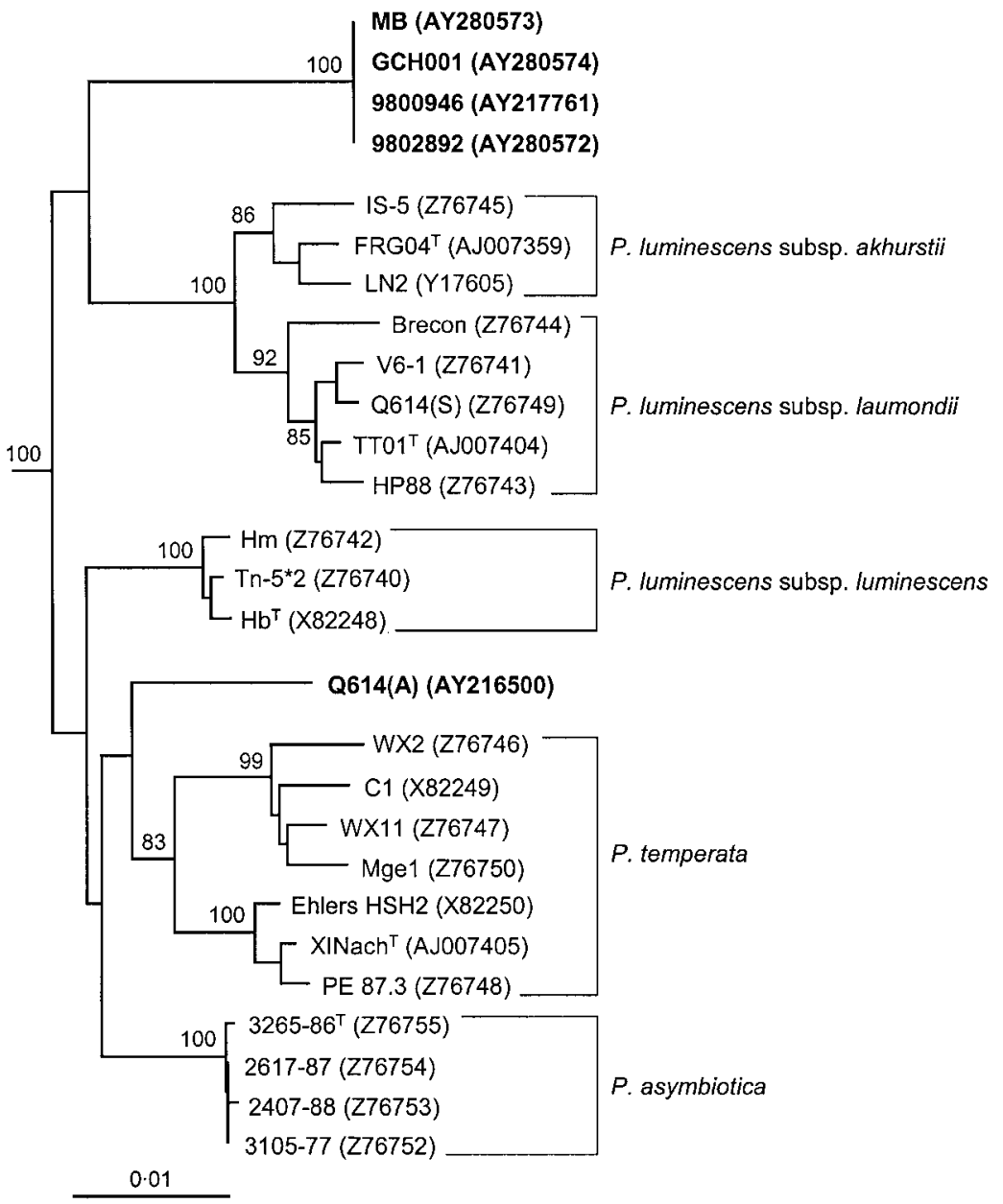

Fig. 1. Evolutionary-distance dendrogram, based on comparative analysis of $16 \mathrm{~S}$ rRNA gene sequences, showing the relationships of four Australian clinical isolates and isolate Q614(A) (shown in bold) to members of the genus Photorhabdus. Recognized groups within the genus are indicated on the right of the figure. The tree was constructed from Jukes \& Cantor (1969) distances by the least-squares algorithm (Fitch \& Margoliash, 1967). The 16S rRNA gene sequences of E. coli (GenBank accession no. J01695) and Proteus vulgaris (X07652) were used as outgroups (not shown). Numbers at branch-points indicate the number of times (expressed as a percentage) that the sequences to the right of the branch-point were recovered as a monophyletic group in a parallel bootstrap analysis of 1000 datasets. GenBank accession numbers for the gene sequences are indicated in parentheses. Bar, 0.01 substitutions per nucleotide position.

and the gyrB sequences of E. coli (X04341) and Xenorhabdus nematophila isolate AN6 (AY322431). Trees were represented graphically with the software TREEvIEW version 1.4 (R. D. M. Page, Division of Environmental and Evolutionary Biology, University of Glasgow, Glasgow, UK).

DNA labelling. High-molecular-mass genomic DNA was sheared by sonication with a Branson sonifier 250 on $50 \%$ duty cycle at power level 5 for a total of $5 \mathrm{~min}$. This produced DNA fragments with an average size of $0.5 \mathrm{~kb}$. The sheared DNA was labelled with ${ }^{32} \mathrm{P}$ by random-primed synthesis using an NEBlot kit (New England Biolabs). Labelled DNA was separated from unincorporated label by gel filtration using Probe-Quant G-50 Micro columns (Amersham Pharmacia Biotech).

DNA-DNA hybridization. Measurements of reassociation between genomes were performed by a modified version of the competitive hybridization method of De Ley et al. (1970). Nitrocellulose membranes (Nitropure, MSI), to which $2 \mu \mathrm{g}$ denatured, high-molecularmass genomic DNA was bound, were incubated with $0 \cdot 2 \mu \mathrm{g}$ sheared, denatured $\left[{ }^{32} \mathrm{P}\right] \mathrm{DNA}$ of the same isolate, in the presence or absence of a 250-fold excess of competitor DNA. Competitor DNA was $50 \mu \mathrm{g}$ unlabelled, sheared, denatured DNA of either the same isolate or another isolate. Hybridization was performed in a buffer of $2 \times$ SSC (Sambrook et al., 1989) $+30 \%(\mathrm{v} / \mathrm{v})$ formamide for $18 \mathrm{~h}$ at $50{ }^{\circ} \mathrm{C}$. After five brief rinses in $2 \times \mathrm{SSC}+0 \cdot 1 \%(\mathrm{w} / \mathrm{v})$ SDS at room temperature, filters were washed twice in the same solution at $50{ }^{\circ} \mathrm{C}$ for $30 \mathrm{~min}$. Filter-bound radioactivity was measured by using a Beckman LS2800 scintillation counter. Reassociation (\%) was calculated as $100 \times$ (counts in the absence of competing DNAcounts with heterologous competing DNA)/(counts in the absence of competing DNA-counts with homologous competing DNA).

Thermal stability of DNA-DNA hybrids was determined after hybridizing, as described above, filter-bound DNA and $\left[{ }^{32} \mathrm{P}\right] \mathrm{DNA}$ of either the same isolate or another isolate. After hybridization, filters were washed five times in $2 \times \mathrm{SSC}+0 \cdot 1 \%$ SDS at room temperature and then incubated in successive $2 \mathrm{ml}$ volumes of $2 \times \mathrm{SSC}+30 \%(\mathrm{v} / \mathrm{v})$ DMSO at a range of temperatures between 50 and $95^{\circ} \mathrm{C}$. The amount of radioactivity released from the filters at each temperature was measured by Cerenkov radiation, with tritium discriminators on a Beckman LS2800 scintillation counter.

$T_{\mathrm{m}}$, defined as the temperature at which $50 \%$ of the radioactive probe remains bound to the filter, was calculated for each hybridization, and the difference in melting temperature between homologous and heterologous duplexes $\left(\Delta T_{\mathrm{m}}\right)$ was used as a measure of the similarity between DNA sequences.

\section{RESULTS AND DISCUSSION}

This polyphasic approach to investigating taxonomic relationships within the genus Photorhabdus shows a clear distinction at the species level between those isolates that were obtained from entomopathogenic nematodes of the genus Heterorhabditis and those obtained from human 


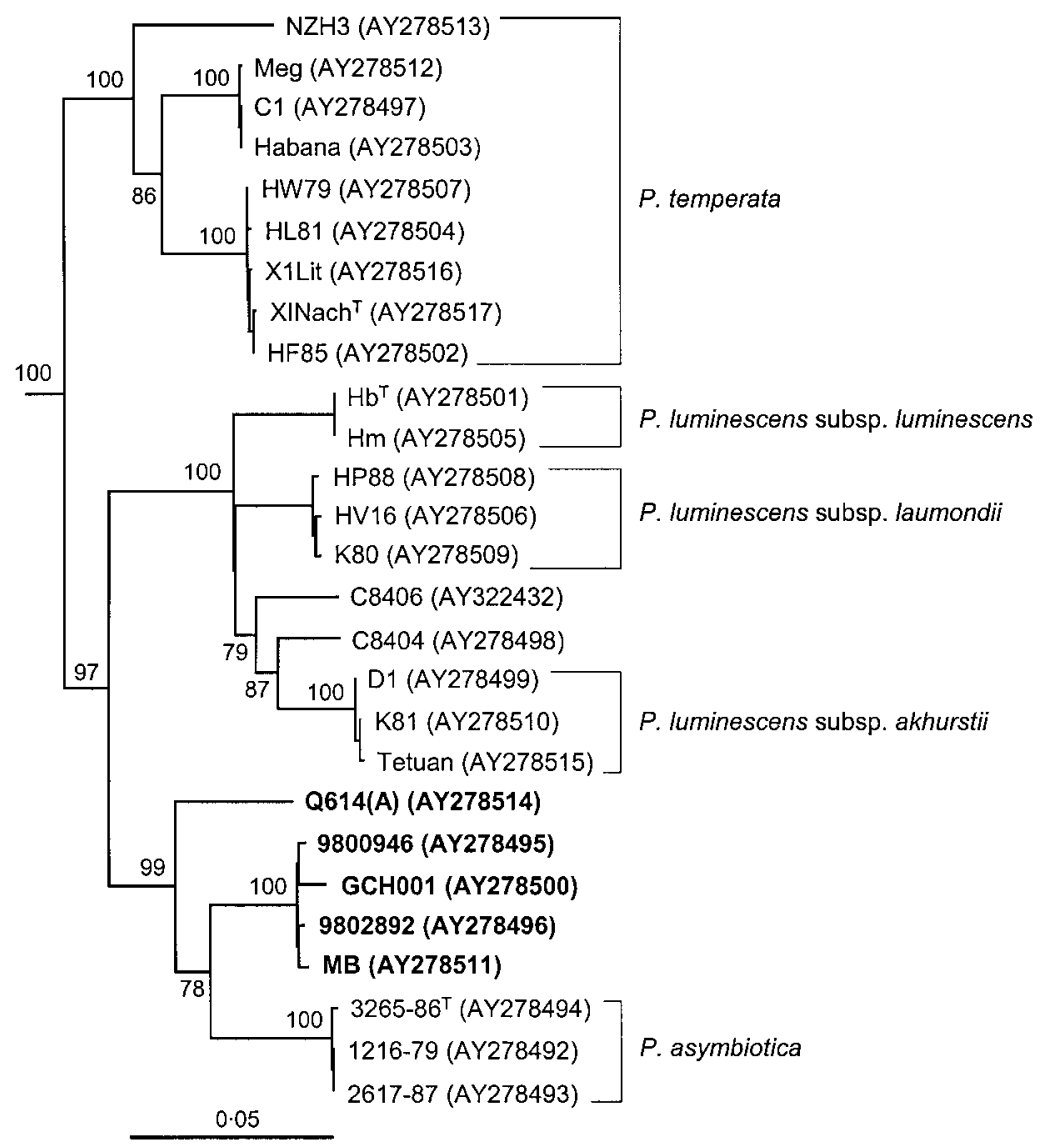

Fig. 2. Evolutionary-distance dendrogram, based on comparative analysis of $g y r B$ sequences, showing the relationships of four Australian clinical isolates and isolate Q614(A) (shown in bold) to members of the genus Photorhabdus. Recognized groups within the genus are indicated on the right of the figure. The tree was constructed from Jukes \& Cantor (1969) distances by the neighbour-joining algorithm (Saitou \& Nei, 1987). The gyrB sequences of $E$. coli (GenBank accession no. X04341) and Xenorhabdus nematophila (AY322431) were used as outgroups (not shown). Numbers at branch-points indicate the number of times (expressed as a percentage) that the sequences to the right of the branch-point were recovered as a monophyletic group in a parallel bootstrap analysis of 1000 datasets. GenBank accession numbers for the gene sequences are indicated in parentheses. Bar, 0.05 substitutions per nucleotide position.

clinical specimens. It also shows that there are two subgroups of isolates from human clinical specimens.

\section{Phenotypic characterization}

Each of the six Australian clinical isolates was Gramnegative, rod-shaped and motile with peritrichous flagella. All were phase II variants; they were not noticeably pigmented on nutrient agar, but were either yellow (9800946), off-white (GCH001) or cream on egg-yolk agar. None adsorbed dye from MacConkey agar or showed antibiotic activity against Micrococcus luteus. Isolate GCH001 showed a weak lecithinase reaction on egg-yolk agar; all others were negative. Few cells produced inclusions. Luminescence was detected in all isolates by scintillation counting, but not usually by the dark-adapted eye, whether the bacteria were in liquid or on solid media. All isolates were positive for catalase, lipase (Tween 20) and gelatin hydrolysis (Kohn's) and were negative for nitrate reduction, oxidase, Voges-Proskauer reaction, hydrogen sulfide production, $\beta$ galactosidase activity with $o$-nitrophenyl $\beta$-D-galactopyranoside, urease, tryptophan deaminase, indole, lysine and ornithine decarboxylases and arginine dihydrolase. All isolates were totally or partially haemolytic on sheep and horse blood agar; annular haemolysis (Akhurst et al., 1996) was observed on sheep blood agar for isolates MB, 9800946 and GCH001, but not for the four isolates that were obtained from one patient (9802336, etc.; see Table 1); none of the isolates displayed annular haemolysis on horse blood agar. Isolate 9800946 exhibited total haemolysis on sheep blood agar and partial haemolysis on horse blood agar, whereas the four isolates from the same patient exhibited partial and total haemolysis on sheep and horse blood agar, respectively. Total haemolysis was recorded for the $\mathrm{MB}$ isolate on both sheep and horse blood agar. Maximum temperature for growth of all Australian clinical isolates was $40{ }^{\circ} \mathrm{C}$, whereas the maximum growth temperature for USA isolates of $P$. asymbiotica was $38^{\circ} \mathrm{C}$.

Acid, but not gas, was produced from glucose by all isolates. Other carbon sources from which acid was produced by all isolates were: fructose, glycerol, $N$-acetyl-D-glucosamine, mannose, maltose and ribose. No acid was produced by any isolate from adonitol, aesculin, amygdalin, L-arabinose, D- or L-arabitol, arbutin, cellobiose, dulcitol, erythritol, D-fucose, galactose, gentiobioise, glycogen, inulin, 2ketogluconate, lactose, D-lyxose, mannitol, melezitose, melibiose, methyl D-glucoside, methyl D-mannoside, raffinose, rhamnose, sorbitol, sorbose, starch, sucrose, D-tagatose, trehalose, D-turanose, xylitol, $\beta$-D-xyloside or D- or L-xylose. All isolates assimilated the following: glucose, mannose, maltotriose, maltose, ribose, glycerol, L-malate, citrate, $\mathrm{N}$-acetyl-D-glucosamine, D-gluconate, succinate, fumarate, L-aspartate, L-glutamate, L-proline, $\mathrm{L}$-alanine and L-serine. None of the following compounds was assimilated by any isolate: DL- $\alpha$-amino- $n$-butyrate, 
adonitol, aesculin, DL- $\alpha$-amino- $n$-valerate, L-arabinose, D- or L-arabitol, benzoate, betaine, caprate, caprylate, D-cellobiose, $m$-coumarate, dulcitol, $i$-erythritol, ethanolamine, $\mathrm{D}$ - $(+)$-galactose, D-galacturonate, $\beta$-gentiobiose, glutarate, DL-glycerate, histamine, L-histidine, $m$-hydroxybenzoate, DL- $\beta$-hydroxybutyrate, hydroxyquinoline- $\beta$ glucuronide, itaconate, 2-keto-D-gluconate, 5-keto-Dgluconate, DL-lactate, $\alpha$-lactose, lactulose, D-lyxose, malonate, maltitol, D-mannitol, D-melezitose, $\alpha$-D- $(+)$ melibiose, methyl $\alpha$-D-glucopyranoside, methyl $\alpha$ galactopyranoside, methyl $\beta$-D-glucopyranoside, methyl $\beta$-galactopyranoside, methyl D-glucopyranose, mucate, 2-oxoglutarate, palatinose, phenyl 3-propionate, phenylacetate, $p$-hydroxybenzoate, protocatechuate, putrescine, quinate, $\mathrm{D}$ - $(+)$-raffinose, $\alpha$-L-rhamnose, D-saccharate, D-sorbitol, L- $(+)$-sorbose, sucrose, D-tagatose, D- $(-)$ tartrate, $\mathrm{L}-(+)$-tartrate, meso-tartrate, trans-aconitate, tricarballylate, trigonelline, tryptamine, L-tryptophan, D-turanose, xylitol or D-xylose.

Each of the six Australian clinical isolates killed Galleria mellonella larvae when injected.

Characters that varied between isolates are presented in Table 2 .

Table 2. Phenotypic characters that varied between the Australian clinical isolates of Photorhabdus

Strains: 1, 9800946; 2, 9802336; 3, 9802397; 4, 9802892 ${ }^{\mathrm{T}} ; 5$, 9805888; 6, MB. +, Positive; -, negative; $+\mathrm{W}$, weakly positive; NT, not tested.

\begin{tabular}{|c|c|c|c|c|c|c|}
\hline Character & 1 & 2 & 3 & 4 & 5 & 6 \\
\hline \multicolumn{7}{|l|}{ Hydrolysis of: } \\
\hline Tween 40 & + & - & - & - & - & - \\
\hline Tween 60 & + & - & - & - & - & - \\
\hline Tween 80 & + & - & - & - & - & - \\
\hline Tween 85 & - & + & + & + & + & + \\
\hline DNase & - & + & + & + & + & + \\
\hline Simmons' citrate & + & + & - & + & + & - \\
\hline \multicolumn{7}{|l|}{ Acidification of: } \\
\hline Inositol & + & $+\mathrm{w}^{\dagger}$ & - & - & + & - \\
\hline Aesculin & + & $+\mathrm{W}$ & - & - & - & - \\
\hline Salicin & + & - & - & - & - & - \\
\hline Gluconate & $+\mathrm{W}$ & + & + & + & + & - \\
\hline 5-Ketogluconate & $+\mathrm{W}$ & - & - & - & - & + \\
\hline \multicolumn{7}{|l|}{ Assimilation of: } \\
\hline Fructose & + & - & - & - & + & NT \\
\hline Trehalose & + & - & - & - & - & NT \\
\hline myo-Inositol & + & $+\mathrm{w}$ & - & $+\mathrm{W}$ & + & NT \\
\hline$\alpha-\mathrm{L}-(-)$-Fucose & $+\mathrm{w}$ & - & - & - & - & NT \\
\hline D-Glucuronate & + & + & - & - & + & NT \\
\hline D-Alanine & + & - & - & - & - & NT \\
\hline Propionate & + & - & - & - & - & NT \\
\hline L-Tyrosine & + & - & + & - & - & NT \\
\hline
\end{tabular}

There were differences between the data reported here and those reported by Peel et al. (1999), who characterized the same isolates, with the exception of GCH001. For example, Peel et al. (1999) reported that the isolates were all positive for urease and negative for DNase and acidification of maltose, whereas this study found no urease activity, that all Australian clinical isolates acidified maltose and that only isolate 9800946 was negative for DNase. Different protocols, involving different temperatures and times of incubation, were employed for many tests in these two studies. Peel et al. (1999) conducted almost all their biochemical tests at $35^{\circ} \mathrm{C}$, whereas the corresponding tests reported here were conducted at $28^{\circ} \mathrm{C}$. The choice of protocols and conditions in the study reported here was made to remain consistent with those used previously to characterize isolates of the genus Photorhabdus (Boemare \& Akhurst, 1988; Fischer-Le Saux et al., 1999). This allowed comparison of the data gathered in this study with those obtained in earlier studies, to test whether the novel taxon suggested by sequence and DNADNA hybridization analyses could be differentiated from existing taxa in the genus Photorhabdus on the basis of phenotypic characters.

\section{DNA-DNA hybridization}

DNA of isolate MB reassociated most strongly with that of the P. asymbiotica isolate $3265-86^{\mathrm{T}}$ (Table 3 ) and its reassociation with isolates from other Photorhabdus spp. was always $<55 \% . \Delta T_{\mathrm{m}}$ for isolate $\mathrm{MB}$ was $>6{ }^{\circ} \mathrm{C}$ for all isolates, except for $3265-86^{\mathrm{T}}\left(4 \cdot 1{ }^{\circ} \mathrm{C}\right)$ and Q614 $(\mathrm{A})\left(4 \cdot 9^{\circ} \mathrm{C}\right)$. DNA of isolate Q614(A) had $52 \%$ reassociation with that of isolate MB and only $31 \%$ with that of isolate $3265-86^{\mathrm{T}}$ of P. asymbiotica.

\section{Phylogenetic analyses}

Analysis of 16S rRNA gene sequences (by four different methods) supported the subspecies-level groupings of isolates of Fischer-Le Saux et al. (1999). These groupings were the same in all analyses. The relationship of these subspecies-level groupings with each other, i.e. their organization into recognized species, was not supported by these analyses. Each different analysis gave different groupings of the subspecies into higher-level clades, and few of these higher-level groupings were given any statistical support (Fig. 1). The 16S rRNA gene sequences of the four Australian clinical isolates were slightly more similar to those from isolates of $P$. asymbiotica (mean Jukes-Cantor-corrected distance, $2.95 \%$; range, 2.91$2.99 \%)$ than to sequences from members of other clusters (mean Jukes-Cantor-corrected distance, 3.66\%; range, $3 \cdot 29-4 \cdot 19 \%)$.

Phylogenies based on 16S rRNA gene sequences have previously been used to distinguish several groups within the genus Photorhabdus that were consistent with DNADNA hybridization and phenotypic data (Szállás et al., 1997; Fischer-Le Saux et al., 1999). However, 16S rRNA gene 
Table 3. DNA-DNA hybridization of isolate $M B$ with isolates representing each species and subspecies of the genus Photorhabdus

For each pair, reassociation values (\%) are the means of duplicate experiments with ${ }^{32} \mathrm{P}$-labelled $\mathrm{MB}$ DNA. $\Delta T_{\mathrm{m}}$ values are means of reverse hybridizations.

\begin{tabular}{|llcc|}
\hline Species & Strain/isolate & Reassociation $(\%)$ & $\Delta \boldsymbol{T}_{\mathbf{m}}\left({ }^{\circ} \mathbf{C}\right)$ \\
\hline P. asymbiotica & $3265-86^{\mathrm{T}}$ & 76 & $4 \cdot 1$ \\
P. luminescens & $\mathrm{C} 8406$ & 47 & $6 \cdot 5$ \\
P. luminescens subsp. luminescens & $\mathrm{Hb}^{\mathrm{T}}$ & 29 & $7 \cdot 5$ \\
P. luminescens subsp. akhurstii & $\mathrm{D} 1$ & 35 & $8 \cdot 1$ \\
P. luminescens subsp. laumondii & $\mathrm{K} 80$ & $23^{*}$ & $7 \cdot 6 \dagger$ \\
P. temperata & $\mathrm{C} 1$ & 37 & $7 \cdot 6$ \\
P. temperata & $\mathrm{XlNach}$ & $8 \cdot 5$ \\
Photorhabdus sp. & $\mathrm{Q} 614(\mathrm{~A})$ & $20^{*}$ & $4 \cdot 9 \dagger$ \\
\hline
\end{tabular}

${ }^{\star}$ Not replicated.

$\dagger$ Determined only with bound DNA from isolate MB.

sequence analysis proved less reliable with the additional set of sequences used in this study. Although phylogenetic analysis of $16 \mathrm{~S}$ rRNA gene sequences supported the grouping of isolates into the subspecies groupings identified by Fischer-Le Saux et al. (1999), these subspecies groupings did not form consistent groups at the species level. Isolates of Photorhabdus luminescens subsp. luminescens did not cluster closely with the other two subspecies of $P$. luminescens, and $P$. asymbiotica could not be distinguished as a separate species (Fig. 1). The inconsistency of the species-level groupings in these analyses suggests that 16S rRNA gene sequence data are not suitable for the definition of species within the genus Photorhabdus, although they are useful at the subspecies level. This is because sequence differences are restricted to a few variable regions, and so the information content is not sufficient to provide reliable species-level groupings. Members of each subspecies displayed sequences that were very similar, even in variable regions, thus drawing the members of the subspecies together.

In contrast to $16 \mathrm{~S}$ rDNA data, the $g y r B$ gene provides useful data for investigating bacterial intrageneric phylogenies (Venkateswaran et al., 1999; Kasai et al., 2000; Yamamoto et al., 2000). The gyrB sequence data for Photorhabdus provided a good match with DNA-DNA hybridization and phenotypic data at both subspecies and species levels (Fig. 2). This is because the proportion of invariant nucleotide positions is lower than in the $16 \mathrm{~S}$ rRNA gene. Each of the four clustering methods tested in the analysis of the $g y r B$ data grouped isolates into the subspecies recognized by Fischer-Le Saux et al. (1999), and then the subspecies into recognized species in a highly reproducible (all four methods) and statistically significant (bootstrap values of $99 \%$ or greater) manner. It is clear from these analyses that the species and subspecies identified by Fischer-Le Saux et al. (1999) are valid.
There may be more than the three subspecies of $P$. luminescens that were proposed by Fischer-Le Saux et al. (1999). In analysis of gyrB sequences, although the two Chinese isolates C8404 and C8406 clustered consistently with $P$. luminescens, the level of sequence divergence suggests that they may not fall into any of the recognized subspecies. Akhurst et al. (1996) showed that these isolates had 64-82\% DNA-DNA reassociation with $P$. luminescens subsp. luminescens isolate $\mathrm{Hb}$ and $P$. luminescens subsp. akhurstii isolate D1. Isolate C8406 forms a discrete PCRRFLP profile, with greatest similarity to those of the $P$. luminescens subsp. luminescens group (Brunel et al., 1997; Fischer-Le Saux et al., 1999) and isolate C8404 produces a novel 16S rRNA gene PCR-RFLP profile that is most similar to that of the P. luminescens subsp. akhurstii group (S. Pages, personal communication). The gyrB, DNA relatedness and PCR-RFLP data suggest that, whilst they are members of the species P. luminescens, isolates C8404 and C8406 do not fall into any recognized subspecies. The gyrB analysis also suggests that they may not belong to a common subspecies.

In all analyses of gyrB sequences, two main clusters of Photorhabdus temperata isolates were formed and isolate NZH3 always branched more deeply, but coherently, with these. The mean Jukes-Cantor-corrected distance between members of different clusters was $4.95 \%$ (range, $4 \cdot 10$ $6.57 \%)$. This suggests that there are three genetically distinct lineages of $P$. temperata, given that levels of sequence divergence between these clusters were similar to those for recognized subspecies of $P$. luminescens (mean JukesCantor-corrected distance between members of different clusters was $5 \cdot 06 \%$, with a range of $4 \cdot 56-5 \cdot 70 \%$ ).

Isolates $\mathrm{MB}, \mathrm{GCH} 001,9800946$ and $9802892^{\mathrm{T}}$ always grouped together and formed a sister group to the cluster of P. asymbiotica isolates. Isolate Q614(A) always branched 
more deeply, but reproducibly, with isolates of $P$. asymbiotica and the Australian clinical isolates. The mean JukesCantor-corrected distance between any of the American isolates of P. asymbiotica and any of the four Australian clinical isolates was $5 \cdot 57 \%$ (range, $5 \cdot 23-6 \cdot 18 \%$ ). Coherence of the branching pattern in all analyses, statistical support for the groupings and the level of sequence divergence between any of the American or Australian clinical isolates and isolate Q614(A) (5·51-7·54\%) all suggested strongly that there are at least three genetically distinct lineages of $P$. asymbiotica. In analyses of gyrB sequences, isolate Q614(A) always grouped with the four Australian clinical isolates and the $P$. asymbiotica isolates; the bootstrap value for this grouping was $100 \%$.

\section{Non-luminescent isolate $\mathbf{Q 6 1 4}$}

The unexpected grouping of the non-luminescent isolate Q614 (Akhurst \& Boemare, 1986) with a subgroup of $P$. luminescens based on comparative $16 \mathrm{~S}$ rRNA gene sequence analysis (Szállás et al., 1997) was investigated. An earlier DNA-DNA hybridization study had shown that isolate Q614, recovered from a nematode host and characterized by two of the authors (R. J.A. and N.E.B), had $<50 \%$ reassociation with the DNA of two $P$. luminescens isolates (Boemare et al., 1993). The correct identity of the original isolate from the CSIRO Culture Collection was demonstrated by its lack of bioluminescence when tested by scintillation counter, as it is the only non-luminescent isolate of Photorhabdus in the CSIRO collection. The 16S rRNA gene sequence of that isolate, labelled Q614(A), had only 95.5\% sequence similarity to the sequence submitted by Szállás et al. (1997), labelled Q614(S). It is evident that the isolate used by Szállás et al. (1997) was identified incorrectly as the non-luminescent isolate Q614 and that the sequence deposited with GenBank accession no. Z76749 is annotated incorrectly. Consequently, the phylogenetic positioning of isolate Q614 in subcluster IV (Szállás et al., 1997) is incorrect.

The verified isolate Q614(A) did not branch consistently with any subspecies grouping in different analyses of $16 \mathrm{~S}$ rRNA gene sequences, which is consistent with our observation that comparative analysis of this gene is not able to group isolates into recognized species. In contrast, analyses of gyrB sequences always grouped Q614(A) with the four Australian clinical isolates and with isolates of P. asymbiotica; the bootstrap value for this grouping was $100 \%$ (Fig. 2). This suggests that Q614(A) may represent a novel subspecies of $P$. asymbiotica. However, DNA-DNA hybridization data suggest that Q614(A) is not conspecific with $P$. asymbiotica, as it had only 52 and $31 \%$ reassociation with isolates $\mathrm{MB}$ and $3265-86^{\mathrm{T}}$, respectively, and a $\Delta T_{\mathrm{m}}$ of nearly $5{ }^{\circ} \mathrm{C}$ with isolate MB (Table 2). As Q614(A) is the only representative of a putative subgroup, it would be prudent to wait until more isolates are available for investigation before a formal decision on its taxonomic position can be made.

\section{Clinical isolates of Photorhabdus}

Both the gyrB phylogeny and DNA-DNA hybridization data show that the Australian and USA clinical isolates are closely related (Fig. 2, Table 2). As isolate MB had $76 \%$ DNA-DNA reassociation and a $\Delta T_{\mathrm{m}}$ of $4 \cdot 1{ }^{\circ} \mathrm{C}$ with P. asymbiotica isolate $3265-86^{\mathrm{T}}$, they meet the definition of Wayne et al. (1987) for being regarded as conspecific. In the phylogenetic analysis conducted with gyrB sequence data, the USA clinical isolates, identified previously as $P$. asymbiotica, and the Australian clinical isolates formed a discrete group, albeit with Q614(A). Further, with each of the four clustering methods employed in the $\operatorname{gyrB}$ analysis, the Australian clinical isolates and the USA clinical isolates formed discrete subgroups. Moreover, DNA-DNA reassociation and $\Delta T_{\mathrm{m}}$ values for the $\mathrm{MB} / 3265-86^{\mathrm{T}}$

Table 4. Phenotypic characters differentiating the Australian clinical isolates from described species of Photorhabdus

Species: 1, P. asymbiotica (Australian clinical isolates); 2, P. asymbiotica (USA clinical isolates); 3, P. luminescens; $4, P$. temperata. Data are from Fischer-Le Saux et al. (1999) and this study. All tests were conducted at $28{ }^{\circ} \mathrm{C}$, unless otherwise noted. Results are indicated as:,$+>90 \%$ isolates positive; $[+], 76-89 \%$ positive; D, $26-75 \%$ positive; [-], $11-25 \%$ positive;,$-<10 \%$ positive; $\mathrm{W}$, weak reaction. Results for isolate $9802892^{\mathrm{T}}$ are presented in parentheses.

\begin{tabular}{|lcccc|}
\hline Character & $\mathbf{1}$ & $\mathbf{2}$ & $\mathbf{3}$ & $\mathbf{4}$ \\
\hline Maximum growth temperature & $40(40)$ & 38 & 39 & 34 \\
$\left.\quad{ }^{\circ} \mathrm{C}\right)$ & & & & \\
Hydrolysis of: & & & & \\
$\quad$ Tween 60 & {$[-](-)$} & + & + & + \\
Tween 80 & {$[-](-)$} & + & + & + \\
DNase & {$[+](+)$} & - & $\mathrm{D}$ & $\mathrm{D}$ \\
Urease & $-(-)$ & + & $\mathrm{D}$ & $\mathrm{D}$ \\
Aesculin hydrolysis & {$[-](-)$} & + & + & {$[+]$} \\
Fermentation of: & & & & \\
Aesculin & $\mathrm{D}(-)$ & {$[+]$} & {$[+]$} & + \\
5-Ketogluconate & $\mathrm{D}(+)$ & $\mathrm{DW}$ & - & {$[-]$} \\
Mannitol & $-(-)$ & - & $\mathrm{D}$ & {$[-]$} \\
Trehalose & $-(-)$ & + & + & {$[+]$} \\
Assimilation of: & & & & \\
L-Fucose & {$[-](-)$} & - & $\mathrm{DW}$ & $\mathrm{D}$ \\
DL-Glycerate & $-(-)$ & $\mathrm{D}$ & - & + \\
L-Histidine & $-(-)$ & $\mathrm{D}$ & $\mathrm{D}$ & {$[+]$} \\
myo-Inositol & {$[+](+\mathrm{W})$} & - & {$[+]$} & $\mathrm{D}$ \\
DL-Lactate & $-(-)$ & - & $\mathrm{DW}$ & - \\
D-Mannitol & $-(-)$ & - & {$[+]$} & - \\
Indole & $-(-)$ & - & + & {$[-]$} \\
Tryptophan deaminase & $-(-)$ & - & - & {$[+]$} \\
Simmons' citrate & $\mathrm{D}(+)$ & $+\mathrm{W}$ & $\mathrm{D}$ & $\mathrm{D}$ \\
Annular haemolysis at $25^{\circ} \mathrm{C}:$ & & & & \\
Sheep blood agar & $-(+)$ & + & $\mathrm{D}$ & $\mathrm{D}$ \\
Horse blood agar & + & $\mathrm{D}$ & {$[+]$} \\
& & & & \\
\hline
\end{tabular}


combination were near the species definition limits of Wayne et al. (1987) of $70 \%$ and $5{ }^{\circ} \mathrm{C}$, respectively, and the two subgroups could be differentiated on the basis of several phenotypic characters (Table 4). On the basis of these differences, we propose that the Australian and USA clinical isolates of the genus Photorhabdus should be assigned to different subspecies of $P$. asymbiotica.

\section{Emended description of Photorhabdus asymbiotica}

Photorhabdus asymbiotica (a.sym.bi.o'ti.ca. Gr. pref $a$ not; N.L. fem. adj. symbiotica living together; N.L. fem. adj. asymbiotica not symbiotic).

Cells are Gram-negative rods of $2-3 \times 0 \cdot 5-1 \cdot 0 \mu \mathrm{m}$ that are motile by peritrichous flagella. Maximum temperature for growth in nutrient broth is $40^{\circ} \mathrm{C}$. Yellow, brown or no pigment. Catalase-positive; oxidase-negative; nitrate is not reduced. Negative for $o$-nitrophenyl $\beta$-D-galactopyranoside activity and the Voges-Proskauer test. Bioluminescent. No phase I isolates have been detected; isolates do not absorb dyes, are negative for lecithinase on egg-yolk agar and are, at most, weakly antibiotic. Positive for Simmons' citrate. Negative for $\mathrm{H}_{2} \mathrm{~S}$ from triple-sugar iron agar, tryptophan deaminase, lysine and ornithine decarboxylases, arginine dihydrolase and indole. Acid is produced from fructose, $\mathrm{N}$-acetylglucosamine, glucose, glycerol, maltose, mannose and ribose. No gas is produced from glucose. Proteinaceous inclusions are produced poorly. Annular haemolysis is usually evident on sheep blood agar at $25^{\circ} \mathrm{C}$. Does not use L-fucose, DL-lactate or mannitol.

The type strain is $3265-86^{\mathrm{T}} \quad\left(=\right.$ ATCC $43950^{\mathrm{T}}=\mathrm{CIP}$ $\left.106331^{\mathrm{T}}=\mathrm{DSM} 15149^{\mathrm{T}}\right)$. Natural habitat is uncertain; all isolates were obtained from human clinical specimens. The GenBank accession numbers for the 16S rRNA and gyrB gene sequences of the type strain are Z76755 (Szállás et al., 1997) and AY278494, respectively.

\section{Description of Photorhabdus asymbiotica subsp. asymbiotica subsp. nov.}

Photorhabdus asymbiotica subsp. asymbiotica (a.sym.bi.o'ti.ca. Gr. pref $a$ not; N.L. fem. adj. symbiotica living together; N.L. fem. adj. asymbiotica not symbiotic).

Maximum temperature for growth in nutrient broth is $37-38^{\circ} \mathrm{C}$. Yellow or brown pigment. Positive for urease and aesculin hydrolysis; weakly positive for Simmons' citrate. Negative for DNase. Acid is produced from trehalose and usually from aesculin; variable for gluconate. Proteinaceous inclusions are produced poorly. Annular haemolysis occurs on sheep blood and horse blood agars. Positive for Tween 60 and Tween 80 esterases; Tween 40 esterase activity is variable.

The type strain is $3265-86^{\mathrm{T}} \quad\left(=\mathrm{ATCC} \quad 43950^{\mathrm{T}}=\mathrm{CIP}\right.$ $\left.106331^{\mathrm{T}}=\mathrm{DSM} 15149^{\mathrm{T}}\right)$. Natural habitat is uncertain; all isolates were obtained from human clinical specimens in the USA. The GenBank accession numbers of the $16 \mathrm{~S}$ rRNA and $g y r B$ gene sequences of the type strain are Z76755 (Szállás et al., 1997) and AY278494, respectively.

\section{Description of Photorhabdus asymbiotica subsp. australis subsp. nov.}

Photorhabdus asymbiotica subsp. australis (aus.tra'lis. L. fem. adj. australis southern; this subspecies was detected in the southern hemisphere).

Maximum temperature for growth is $40^{\circ} \mathrm{C}$. Yellow or no pigment; weakly pigmented. Most isolates are positive for DNase and most are negative for aesculin hydrolysis. Negative for urease. Most isolates produce acid from gluconate; variable for acid production from aesculin and negative for trehalose. Proteinaceous inclusions are rare. Annular haemolysis is variable on sheep blood and horse blood agars. Most isolates are negative for Tween 60 and Tween 80 esterases and most grow on myo-inositol.

The type strain is $9802892^{\mathrm{T}}\left(=\operatorname{CIP} 108025^{\mathrm{T}}=\right.$ ACM $\left.5210^{\mathrm{T}}\right)$. Natural habitat is uncertain; all isolates were obtained from human clinical specimens in Australia. The GenBank accession numbers of the 16S rRNA and gyrB gene sequences of the type strain are AY280572 and AY278496, respectively.

\section{ACKNOWLEDGEMENTS}

The expert technical assistance of L. Court, P. Dobson, C. Laroui, R. Mourant, S. Pages and A. Sriskantha is gratefully acknowledged.

\section{REFERENCES}

Akhurst, R. J. (1980). Morphological and functional dimorphism in Xenorhabdus spp., bacteria symbiotically associated with the insect pathogenic nematodes Neoaplectana and Heterorhabditis. J Gen Microbiol 121, 303-309.

Akhurst, R. J. (1983). Taxonomic study of Xenorhabdus, a genus of bacteria symbiotically associated with insect pathogenic nematodes. Int J Syst Bacteriol 33, 38-45.

Akhurst, R. J. (1987). Use of starch gel electrophoresis in the taxonomy of the genus Heterorhabditis (Nematoda: Heterorhabditidae). Nematologica 33, 1-9.

Akhurst, R. J. \& Boemare, N. E. (1986). A non-luminescent strain of Xenorhabdus luminescens (Enterobacteriaceae). J Gen Microbiol 132, 1917-1922.

Akhurst, R. J., Bedding, R. A., Bull, R. M. \& Smith, D. R. J. (1992). An epizootic of Heterorhabditis spp. (Heterorhabditidae: Nematoda) in sugar cane scarabaeids (Coleoptera). Fundam Appl Nematol 15, 71-73.

Akhurst, R. J., Mourant, R. G., Baud, L. \& Boemare, N. E. (1996). Phenotypic and DNA relatedness between nematode symbionts and clinical strains of the genus Photorhabdus (Enterobacteriaceae). Int $J$ Syst Bacteriol 46, 1034-1041.

Bedding, R. A. \& Miller, L. A. (1981). Use of a nematode, Heterorhabditis heliothidis, to control black vine weevil, Otiorhynchus sulcatus, in potted plants. Ann Appl Biol 99, 211-216. 
Bleakley, B. \& Nealson, K. H. (1988). Characterization of primary and secondary forms of Xenorhabdus luminescens strain Hm. FEMS Microbiol Ecol 53, 241-250.

Boemare, N. E. \& Akhurst, R. J. (1988). Biochemical and physiological characterization of colony form variants in Xenorhabdus spp. (Enterobacteriaceae). J Gen Microbiol 134, 751-761.

Boemare, N. E., Akhurst, R. J. \& Mourant, R. G. (1993). DNA relatedness between Xenorhabdus spp. (Enterobacteriaceae), symbiotic bacteria of entomopathogenic nematodes, and a proposal to transfer Xenorhabdus luminescens to a new genus, Photorhabdus gen. nov. Int J Syst Bacteriol 43, 249-255.

Brunel, B., Givaudan, A., Lanois, A., Akhurst, R. J. \& Boemare, N. (1997). Fast and accurate identification of Xenorhabdus and Photorhabdus species by restriction analysis of PCR-amplified 16S rRNA genes. Appl Environ Microbiol 63, 574-580.

De Ley, J., Cattoir, H. \& Reynaerts, A. (1970). The quantitative measurement of DNA hybridization from renaturation rates. Eur J Biochem 12, 133-142.

Farmer, J. J., III, Jorgensen, J. H., Grimont, P. A. D. \& 8 other authors (1989). Xenorhabdus luminescens (DNA hybridization group 5) from human clinical specimens. J Clin Microbiol 27, 1594-1600.

Felsenstein, J. (1989). PHYLIP - Phylogeny inference package (version 3.2). Cladistics 5, 164-166.

Fischer-Le Saux, M., Viallard, V., Brunel, B., Normand, P. \& Boemare, N. E. (1999). Polyphasic classification of the genus Photorhabdus and proposal of new taxa: P. luminescens subsp. luminescens subsp. nov., P. luminescens subsp. akhurstii subsp. nov., $P$. luminescens subsp. laumondii subsp. nov., $P$. temperata sp. nov., $P$. temperata subsp. temperata subsp. nov. and $P$. asymbiotica sp. nov. Int J Syst Bacteriol 49, 1645-1656.

Fitch, W. M. \& Margoliash, E. (1967). Construction of phylogenetic trees. Science 155, 279-284.

Gerrard, J. G., McNevin, S., Alfredson, D., Forgan-Smith, R. \& Fraser, N. (2003). Photorhabdus species: bioluminescent bacteria as emerging human pathogens? Emerg Infect Dis 9, 251-254.

Jukes, T. H. \& Cantor, C. R. (1969). Evolution of protein molecules. In Mammalian Protein Metabolism, pp. 21-132. Edited by H. N. Munro. New York: Academic Press.

Kasai, H., Tamura, T. \& Harayama, S. (2000). Intrageneric relationships among Micromonospora species deduced from gyrBbased phylogeny and DNA relatedness. Int J Syst Evol Microbiol 50, 127-134.

Peel, M. M., Alfredson, D. A., Gerrard, J. G., Davis, J. M., Robson, J. M., McDougall, R. J., Scullie, B. L. \& Akhurst, R. J. (1999). Isolation, identification, and molecular characterization of strains of
Photorhabdus luminescens from infected humans in Australia. J Clin Microbiol 37, 3647-3653.

Poinar, G. O., Jr, Thomas, G. M. \& Hess, R. (1977). Characteristics of the specific bacterium associated with Heterorhabditis bacteriophora (Heterorhabditidae: Rhabditida). Nematologica 23, 97-102.

Poinar, G. O., Jr, Thomas, G. M., Haygood, M. \& Nealson, K. H. (1980). Growth and luminescence of the symbiotic bacteria associated with the terrestrial nematode, Heterorhabditis bacteriophora. Soil Biol Biochem 12, 5-10.

Poinar, G. O., Jr, Jackson, T. \& Klein, M. (1987). Heterorhabditis megidis sp. n. (Heterorhabditidae: Rhabditida), parasitic in the Japanese beetle, Popillia japonica (Scarabaeidae: Coleoptera), in Ohio. Proc Helminthol Soc Wash 54, 53-59.

Saitou, N. \& Nei, M. (1987). The neighbor-joining method: a new method for reconstructing phylogenetic trees. Mol Biol Evol 4, 406-425.

Sambrook, J., Fritsch, E. F. \& Maniatis, T. (1989). Molecular Cloning: a Laboratory Manual, 2nd edn. Cold Spring Harbor, NY: Cold Spring Harbor Laboratory.

Smits, P. H. \& Ehlers, R.-U. (1991). Identification of Heterorhabditis spp. by morphometric characters and RFLP and of their symbiotic bacteria Xenorhabdus by species-specific DNA probes. IOBC/WPRS Bull 14, 195-201.

Szállás, E., Koch, C., Fodor, A., Burghardt, J., Buss, O., Szentirmai, A., Nealson, K. H. \& Stackebrandt, E. (1997). Phylogenetic evidence for the taxonomic heterogeneity of Photorhabdus luminescens. Int J Syst Bacteriol 47, 402-407.

Thompson, J. D., Gibson, T. J., Plewniak, F., Jeanmougin, F. \& Higgins, D. G. (1997). The CLUSTAL_X windows interface: flexible strategies for multiple sequence alignment aided by quality analysis tools. Nucleic Acids Res 25, 4876-4882.

Venkateswaran, K., Moser, D. P., Dollhopf, M. E. \& 10 other authors (1999). Polyphasic taxonomy of the genus Shewanella and description of Shewanella oneidensis sp. nov. Int J Syst Bacteriol 49, 705-724.

Wayne, L. G., Brenner, D. J., Colwell, R. R. \& 9 other authors (1987). International Committee on Systematic Bacteriology. Report of the ad hoc committee on reconciliation of approaches to bacterial systematics. Int J Syst Bacteriol 37, 463-464.

Yamamoto, S. \& Harayama, S. (1995). PCR amplification and direct sequencing of gyrB genes with universal primers and their application to the detection and taxonomic analysis of Pseudomonas putida strains. Appl Environ Microbiol 61, 1104-1109.

Yamamoto, S., Kasai, H., Arnold, D. L., Jackson, R. W., Vivian, A. \& Harayama, S. (2000). Phylogeny of the genus Pseudomonas: intrageneric structure reconstructed from the nucleotide sequences of gyrB and $r p o D$ genes. Microbiology 146, 2385-2394. 